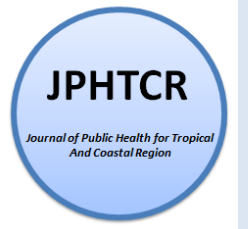

JOURNAL OF PUBLIC HEALTH FOR TROPICAL AND COASTAL REGION (JPHTCR)

Journal homepage: http:/ejournal2.undip.ac.id/index.php/jphtr/index

ISSN : 2597-4378

Research Article

\title{
Influence of amount of pesticide and amount of PPE to diastolic blood pressure of farmers in Bumen Village, Sumowono District, Semarang Regency
}

\author{
Atka Kurnia Sari ${ }^{a}$, Tri Joko $^{a}$, Nikie Astorina Yunita Dewanti ${ }^{a}$ \\ ${ }^{a}$ Environmental Health Department of Public Health Diponegoro University Semarang \\ Correspondence : kurniaatk@gmail.com
}

\begin{abstract}
Background: Farmers in Bumen Village used pesticide from group of organophospat, carbamate, piretroid, and nicotinoid. The dose of pesticide that mix in one tank is not appropriate dosage. A preliminary survey found that farmers mixed more than a two types of pesticides and $100 \%$ of farmers did not use the complete Personal Protective Equipment (PPE) when preparing pesticides to spray. Hypertension is more prevalent in males with an $18.8 \%$ prevalence in Sumowono District in 2015 and becomes the number one disease each month in 2017. The purpose of this study was to determine the influence of the amount of pesticide and the amount of PPE with diastolic blood pressure in farmers in Bumen Village, Sumowono District, Semarang Regency. Independent variables were amount of pesticide and amount of PPE. Dependent variable was diastolic blood pressure.

Methods: This study was observational with cross sectional design using purposive sampling. Samples were 35 respondents. The measurement methods were questionnaire and digital tensimeter. Data analysis used Rank Spearman.

Results: The results showed that measurement of diastolic blood pressure has an average of $88.75 \mathrm{mmHg}$. The amount of pesticide ( $\mathrm{p}=0,007 ; \mathrm{r}=0,455)$ had an influence with diastolic blood pressure, positive correlation, the strenght of correlation was enough and the amount of PPE ( $p=0,034 ; r=-0,36)$ had an influence with diastolic blood pressure, negative correlation, the strenght of correlation was enough

Conclusions: From this study can be concluded that the amount of pesticide and the amount of PPE affected the diastolic blood pressure in farmers in Bumen Village, Sumowono District, Semarang Regency.
\end{abstract}

Keywords: pesticide, farmers, diastolic blood pressure, personal protection equipment, hypertension

\section{Background}

The most commonly used pesticides in Central Java are insecticide $(77,22 \%)$, followed by fungicide $(16,7 \%)$, herbicide $(15,75)$, and unregistered pesticide $(3,0 \%)$. Doses of pesticides are used under recommended doses up to three times of the recomennded doses. Farmers measure the pesticide volume by estimated using the cap's packaging and tablespoon without used the correct serving. Most pesticides are applied to the plant by spraying using mixed pesticides. The amount of pesticides in an average mixture is 2-4 types up to 8 types in one aplication. Average spraying frequency is 2-3 times/week depending on the intensity of pest attack. ${ }^{1}$

Ma'arif, et al's research in 2016 showed that $57.9 \%$ of farmers had low cholinesterase in Mendongan Village, Sumowono District. Low cholinesterase levels of less than $75 \%$ indicate that there has been poisoning in the body. $^{2}$ 
Indriyaningsih BA's research in 2002 showed as many as $65.63 \%$ of farmers in Bumen Village Sumowono District experienced pesticide poisoning as evidenced by cholinesterase levels low. ${ }^{3}$

Hypertension indicated by blood pressure $\geq 140$ / $90 \mathrm{mmHg}{ }^{4}$ Diastolic blood pressure is more appropriate to be used as a determinant of hypertension. Based on the health profile of Sumowono District in 2015, hypertension patients were more prevalent in males with $18.8 \% .^{5}$

The result of interview with Balai Penyuluh Pertanian (BPP) officer of Sumowono District, all horticulture farmers in the district used pesticide as pest control and the pesticide that used in Bumen Village still not according to the correct dose. Puskesmas Sumowono has a farmer development program that includes socialization activities on farmers' health and health check up. The program covers 8 out of 16 existing villages: Jubelan, Sumowono, Bumen, Mendongan, Losari, Piyanggang, Kemawi, and Pledokan villages. The program is only active in two villages namely Jubelan and Sumowono.

Farmers in Bumen Village mixed more than two types of pesticides in agricultural water flows and $100 \%$ of farmers did not use the complete Personal Protective Equipment (PPE) when spraying. Thus, the farmers in the village become one of the vulnerable groups exposed to pesticides.

\section{Methods}

The research was observational with cross sectional study design. The independent variables and the dependent variables were tested using Rank Spearman test. The sampling was purposive sampling with amount of sample was 35 farmers. The data were collected using questionnaires and blood pressure measurements using digital tensimeter with three times of the measurement every five minutes.

\section{Results}

The data in Table 1 shows that the amount of pesticides per spray has an average of 10.77 bottle caps with the minimum uses is 0 bottle caps, and maximum uses is 48 bottle caps. The amount of PPE used by the respondent during spraying has an average of 4.49 items with the number of APD at least 1 item, at most 6 items.Diastolic blood pressure of respondents had an average is $88.75 \mathrm{mmHg}$ with the lowest diastolic blood pressure is $69 \mathrm{mmHg}$, and the highest is $110 \mathrm{mmHg}$.

\begin{tabular}{lllll}
\hline No. & Variables & Min & Max & Mean \\
\hline 1. & The amount of pesticide (cap's bottle) & 0 & 48 & 10,77 \\
2. & The amount of PPE (item) & 1 & 6 & 4,49 \\
3. & Diastolic blood pressure (mmHg) & 69 & 110 & 88,75
\end{tabular}

Table 1. Univariat Analysis

The data in Table 2 shows that the amount of pesticides per spraying is related to the diastolic blood pressure known from the $\mathrm{p}$ value $=0.007$ and $\mathrm{r}=0.445$ which means the higher the amount of pesticides, the higher the diastolic blood pressure with the strength of the relationship is strong enough. The amount of PPE is related with diastolic blood pressure is known from the value of $p$ value $=0.034$ and $r$ arithmetic 0.36 , which means the less amount of PPE used, the higher the diastolic blood pressure with the strength of the relationship strong enough 


\begin{tabular}{llcl}
\hline No. & Influences & $\mathrm{r}$ & $\mathrm{p}$ \\
\hline 1. & The amount of pesticide with diastolic blood pressure & 0,445 & 0,007 \\
2. & The amount of PPE with diastolic blood pressure & $-0,360$ & 0,034
\end{tabular}

Table 2. Result of Rank Spearman Test

\section{Discussion}

The amount of PPE used by the respondent during spraying has an average of 4.49 items with the number of APD at least 1 item, at most 6 items. Farmers wear about 4 PPEs without regard to the importance of PPE. The interviews conducted showed that most farmers use PPE in the form of hats, long sleeves, trousers, and boots. The amount not only comes from one type of liquid pesticide that is insecticide and herbicide.

In this exposure, pesticide doses are not measurable and pesticide concentrations in each tank can not be measured for accuracy. Excessive doses will make the concentration of the mixture increase and produce vapors that can enter through the human respiratory system and will show symptoms of poisoning. ${ }^{6}$

Diastolic blood pressure of respondents had an average is $88.75 \mathrm{mmHg}$ with the lowest diastolic blood pressure is $69 \mathrm{mmHg}$, and the highest is $110 \mathrm{mmHg}$. Blood pressure measurements result indicated prehypertension because the diastolic blood pressure is between 80-89 $\mathrm{mmHg}$. Prehypertension is present in abdominal obesity.

Research that has been done, not accompanied by measurement of respondent IMT. However, based on observations, there are no obese subjects including abdominal obesity, which is usually much in men. Men are at higher risk for prehypertension. Men had an estimated 2 times higher risk of prehypertension than women. ${ }^{7}$
The result of the amount of pesticide occours because in the form of insecticide and liquid herbicide per bottle cap mixed by the farmer each tank will increase according to the number of tanks spent in a single spraying. The amount of insecticides widely used include the Curacron 500 EC, Demolish 18 EC, and Dursban 200 EC. The amount of herbicides widely used is Roundup 486 SL. The higher the amount of pesticides used, the more likely the amount of pesticides entering the body more and more.

The size of the bottle cap can not be precisely measured. The size of the pesticide bottle cap differs from the small equivalent of $5 \mathrm{ml}$, medium $10-15 \mathrm{ml}$, and large $20 \mathrm{ml}$. Nor can the size be an absolute measure because farmers estimate the pesticide fluid in the bottle cap they use. Thus, it can not be known whether in one tank the dose is appropriate or not with the actual dose. If the dosage with the amount of bottle caps mixed in the tank is appropriate, it will be appropriate in killing the non-resistant pest.

The dosage with the number of bottle caps mixed in the tank is less, so there will be no effect on the sprayed plant and the accumulation that comes into the body is also not much due to the low concentration. Conversely, if the pest has been resistant and forced farmers to increase the amount of pesticides in the dissolution then, it is feared the concentration of the solution will be higher. This is often case and farmers will increase the number or change the type of pesticide that is felt better in killing the resistant pest. Excessively high 
concentrations can increase accumulation if exposed and enter the body.

The dosage of pesticide can not be measured in its suitability and pesticide concentration in each tank can not be measured accurately. If excessive doses will make the concentration of the mixture increase and produce vapor that can enter through the human respiratory system and poisoning symptoms will appear. ${ }^{6}$

In another study did not analyze the amount of pesticides in bottle caps but rather the suitability of the pesticide doses used by assessing whether farmers pay attention the dosage present on the liquid pesticide label prior to dissolution. The amount of PPE is related with diastolic blood pressure is known from the value of $\mathrm{p}$ value $=0.034$ and $\mathrm{r}$ arithmetic -0.36 , which means the less amount of PPE used, the higher the diastolic blood pressure with the strength of the relationship strong enough. These results occur because more and more portals of entry are protected, the more minimize the entry of pesticides into the body.

The use of PPE is very important in every job, especially work directly related to hazard such as pesticide which is chemical hazard for farmers. At the time of spraying activity, the completeness of personal protective equipment should take precedence as it will affect the amount of pesticides that enter the body. ${ }^{8}$ Direct contact between farmers and pesticides when spraying can be avoided by the use of complete PPE. Types of personal protective equipment that can be used at least are:

1) Hat to protect the head

2) Mask for protect the nose (respiratory tract)

3) Long-sleeved shirt to protect the body

4) Trousers to protect the body

5) Boots to protect the feet

6) Gloves to protect hands

7) Glasses or goggles to protect the eyes. ${ }^{9,10,11}$
As is known that pesticides enter the body through several ways of inhalation, ingestion, and absorption of the skin. The main pathway of the entry of pesticides into the body in the spraying farmers is the inhalation and absorption of the skin. Pesticides that are sprayed particles will be in the air and can be inhaled simultaneously while breathing. The absence of a shield on the respiratory inlet allows the particles of pesticide chemicals to enter in large quantities.

The sprayed pesticide will definitely stick to the body of the sprayer. Hands become one of the pathways of pesticides whose absorption can occur directly when not using a protector. Therefore, the portal of entry of both lines must be closed. The amount of PPE used in this study was not in line with the Zulfania study in 2017 which showed no association between the amount of PPE use and diastolic blood pressure. The amount of PPE that is covered in the research is 5 items. While in this study, the number of APD used has an average of 4 items. $^{12}$

\section{Conclusions}

There is a fairly strong influence between the amount of pesticides and the amount of PPE with an increase in diastolic blood pressure. Exposure to pesticides is harmful to health. The use of PPE such as masks, hats, gloves, long sleeves, trousers, and boots when spraying for farmers must still be considered when spraying so that in large quantities spraying can protect themselves and minimize the accumulation of pesticides in the body. The farmers shoulf use a measuring instrument to measure the pesticide when dissolving that is usually present on the pesticide packaging.

\section{Competing interest}

The authors declare that they have no competing interests 


\section{References}

1. Kurnia, Nurhasan. Identifikasi Potensi Pencemaran Residu Pestisida di Lahan Pertanian Jawa Tengah. Prosiding Seminar Fakultas Pertanian. UNS. (2017)

2. M.I. Ma'arif, Suhartono, N.A.Y. Dewanti. Studi Prevalensi Keracunan Pestisida pada Petani Penyemprot Sayur di Desa Mendongan Kecamatan Sumowono Kabupaten Semarang. JKM (e-Journal). 4, 5 (2016)

3. B.A. Indriyaningsih. Hubungan Faktor-Faktor Pemaparan Pestisida pada Petani Penyemprot Terhadap Aktifitas Kholinesterase dalam Darah Petani di Desa Bumen, Kecamatan Sumowono, Kabupaten Semarang. Fakultas Kesehatan Masyarakat UNDIP. (2002). Downloaded on March $18^{\text {th }} 2018 . \quad$ [Online]. http://eprints.undip.ac.id/8505/1/1432.pdf

4. M.N. Bustan. Epidemiologi:Penyakit Tidak Menular. Jakarta: Rineka Cipta. (2002)

5. Health Profile of Sumowono District 2015

6. R.A. Tsani, O. Setiani, N.A.Y. Dewanti. Hubungan Riwayat Pajanan Pestisida dengan Gangguan Fungsi Hati pada Petani di Desa Sumberejo Kecamatan Ngablak Kabupaten Magelang. JKM (e-Journal) 5, 3 (2017)

7. L.Churniawati, Santi M., Chatarina U.W. Prehipertensi pada Obesitas Abdominal. JKMN 9, 4 (2015)

8. S.A. Kurniasih, O. Setiani, S.A. Nugraheni. Faktor-Faktor yang Terkait Paparan Pestisida dan Hubungannya dengan Kejadian Anemia pada Petani Hortikultura di Desa Gombong Kecamatan Belik Kabupaten Pemalang Jawa Tengah. JKLI 12, 2 (2013)

9. P.A. Ipmawati, O. Setiani, Y.H Darundiati. Analisis Faktor - Faktor Risiko yang Mempengaruhi Tingkat Keracunan Pestisida pada Petani di Desa Jati, Kecamatan Sawangan, Kabupaten Magelang, Jawa Tengah. JKM (eJournal) 4, 1 (2016)

10. E.L. Mahyuni. Faktor Risiko dalam Penggunaan Pestisida terhadap Keluhan Kesehatan pada Petani di Kecamatan Berastagi Kabupaten Karo 2014. Kesmas 9, 1 (2015)

11. E.R. Wismaningsih, D.I. Oktaviasari. Identifikasi Jenis Pestisida dan Penggunaan APD pada Petani Penyemprot di Kecamatan Ngantru Kabupaten Tulungagung. Jurnal Wiyata, 3, 1 (2016)

12. K.D. Zulfania, O.Setiani, H.L. Dangiran. Hubungan Riwayat Paparan Pestisida dengan Tekanan Darah pada Petani Penyemprot di Desa Sumberejo Kecamatan Ngablak Kabupaten Magelang. JKM (e-Journal) 5, 3 (2017) 